\title{
Erratum: Synergistic effects of ion transporter and MAP kinase pathway inhibitors in melanoma
}

Ugur Eskiocak, Vijayashree Ramesh, Jennifer G. Gill, Zhiyu Zhao, Stacy W. Yuan, Meng Wang, Travis Vandergriff, Mark Shackleton, Elsa Quintana, Arthur E. Frankel, Timothy M. Johnson, Ralph J. DeBerardinis \& Sean J. Morrison

Nature Communications 7:12336 doi: 10.1038/ncomms12336 (2016); Published 22 Aug 2016; Updated 29 Sep 2016

Arthur E. Frankel, who helped to interpret the clinical relevance of the findings, was inadvertently omitted from the authors list during the final stages of production. This has now been corrected in both the PDF and HTML versions of the Article.

\footnotetext{
(c) (i) This work is licensed under a Creative Commons Attribution 4.0 International License. The images or other third party material in this article are included in the article's Creative Commons license, unless indicated otherwise in the credit line; if the material is not included under the Creative Commons license, users will need to obtain permission from the license holder to reproduce the material. To view a copy of this license, visit http://creativecommons.org/licenses/by/4.0/

(C) The Author(s) 2016
} 